\title{
Biohydrogen production by fermentive bacterium Clostridium sp. Tr2 using batch fermenter system controlled pH under dark fermentation
}

\author{
Sản xuất hydro sinh học nhờ vi khuẩn lên men Clostridium sp. Tr2 bằng cách \\ lên men tối theo mé có kiểm soát pH
}

Research article

Nguyen Thi Thu Huyen ${ }^{1,2} *$, Dang Thi Yen ${ }^{1}$, Lai Thuy Hien ${ }^{1}$

${ }^{1}$ Institute of Biotechnology, Vietnam Academy of Science and Technology, 18 Hoang Quoc Viet, Cau Giay, Ha Noi, Vietnam; ${ }^{2}$ Faculty of Biotechnology, Ho Chi Minh City University of Food Industry, 140 Le Trong Tan, ward 15, Tan Phu district, Ho Chi Minh city, Vietnam

\begin{abstract}
Limitation of fuels reserves and contribution of fossil fuels to the greenhouse effect leads to develop a new, clean and sustainable energy. Among the various options, biohydrogen appears as a promising alternative energy source. The fermentative hydrogen production process holds a great promise for commercial processes. Hydrogen production by fermentative bacteria is a very complex and greatly influenced by $\mathrm{pH}$. This paper presents biohydrogen production by bacterial strain Clostridium sp. Tr2. Operational $\mathrm{pH}$ strongly affected its hyrogen production. Its gas production rate as well as obtained gas product were roughly increase twice under controlled $\mathrm{pH}$ at 6 than non-controlled condition. Dark fermentation for hydrogen production of strain Tr2 was performed under bottle as well as automatic fermenter scale under optimal nutritional and environmental conditions at $30^{\circ} \mathrm{C}$, initial $\mathrm{pH}$ at 6.5 , then $\mathrm{pH}$ was controlled at 6 for bioreactor scale (BioFlo 110). Bioreactor scale was much better for hydrogen production of strain Tr2. Clostridium sp. Tr2 produced $0.74 \mathrm{~L}$ hydro (L medium) ${ }^{-1}$ occupying $72.6 \%$ of total gas under bottle scale while it produced $2.94 \mathrm{~L}$ hydro (L medium) $)^{-1}$ occupying $95.82 \%$ of total gas under fermenter scale. Its maximum obtained hydrogen yield of Clostridium sp. Tr2 under bioreactor scale Bioflo 110 in optimal medium with controlled pH 6 was 2.31 mol hydro (mol glucose) $)^{-1}$.
\end{abstract}

Dụ trũ nhiên liệu có giới hạn và việc sủ dụng nhiên liêu hoá thạch góp phần không nhỏ gây hiệu úng nhà kính dẫn đến cần phải phát triển năng luợng mới, sạch và bền vũng. Trong số các giải pháp, hydro sinh học xuất hiện nhu một nguồn năng luợng thay thế đầy hưa hẹn. Quá trình lên men sản xuất hydro có tiềm năng lớn để áp dụng trong sản xuất thuơng mại. Tuy nhiên qúa trình này rất phức tạp và chịu ảnh hưởng lớn bởi $p H$. Nghiên cưu này trình bày sản xuất hydro sinh hoc do chủng vi khuẩn Clostridium sp. Tr2. Quá trình sản xuất hydro của chủng này bị ảnh huoơng mạn mẽ bởi $p H$ thay đổi trong quá trình lên men. Tốc độ tạo khí cũng nhu lượng khí thu được của chủng này tăng gần gấp đôi trong môi trường có duy trì pH ở pH 6 so với môi truò̀ng không kiểm soát pH. Quá trình lên men tối sản xuất hydro của chủng Tr2 được thực hiện ở quy mô bình thí nghiệm cũng nhu bình lên men tụ động trong điều kiện môi truờng tối ưu ở $30^{\circ} \mathrm{C}$, pH ban đầu 6.5, ở qui mô bình lên men tụ động (BioFlo 110), pH môi trường sau đó được duy trì ổn định ở $p H$ 6. Lên men sản xuất hdyro của chủng Tr2 trong bình lên men tụ động tốt hơn rất nhiều so với lên men trong bình thi nghiệm. Clostridium sp. Tr2 chi tạo ra được 0,74 L hydro (L medium)-1 chiếm $72,6 \%$ tổng thể tích khí thu được ở điều kiện lên men bình thí nghiệm trong khi chủng này sản xuất được 2,94 L hydro (L medium) ${ }^{-1}$ chiếm 95,82\% tổng thể tích khi ở điều kiện lên men tụ động. Sản luọng hydro thu được lớn nhất của chủng này trong bình lên men tụ động BioFlo 110 trong trong môi trường tối uu có kiểm soát pH tại pH 6 là 2,31 mol hydro (mol glucose) ${ }^{-1}$.

Keywords: biohydrogen, dark fermentation, batch condition, Clostridium, Vietnam 


\section{Introduction}

Environmental pollution due to the use of fossil fuels as well as their short fall have led most of the countries to invest in research on alternative sources of energy to resolve the issues of environment protection and energy security, and to slow down the climate change. Amongst the different alternatives, biohydrogen appears as a promising energy source that is cost-effective, environmentfriendly and renewable. It has highest specific energy content per unit mass of any known fuel and produces only water as the by-product, when it is combusted as a fuel or converted to electricity (Kotay and Das, 2008; Mudhoo et al., 2011; Kothari et al., 2012; Gupta et al., 2013; Shah et al., 2017). Biohydrogen production can be achieved by fermentative hydrogen production (dark fermentation) as well as photosynthetic hydrogen production (photo-fermentation). However, a fermentative hydrogen production process by strict/facultative anaerobes holds a great promise for commercial processes. There are a number of advantages of this process such as using the vast majority of substrates, no inhibitory effect of oxygen, higher hydrogen production efficiency, higher hydrogen production stability, higher feasibility for industrialization, simpler control requirement, and lower operating costs (Das and Veziroglu, 2008; Kotay and Das, 2008; Lee et al., 2010; Ntaikou et al., 2010; Ren et al., 2011; Show et al., 2012; De Gioannis et al., 2013; Wong et al., 2014). Thus, it has received considerable attention during the recent years.

Fermentative hydrogen production is a very complex process and is greatly influenced by many nutrient and environmental factors, especially $\mathrm{pH}$. Various researchers have shown the influence of $\mathrm{pH}$ to improve hydrogen yields and rate of productivity (Skonieczny and Yargeau, 2009; Khanal et al., 2011; Liu et al., 2011; Chu et al., 2013). In the present study, the effect of operational $\mathrm{pH}$ on hydrogen production was investigated and the dark fermentation for hydrogen production under different scales (bottle and automatic fermentor) was performed using the newly hydrogen-producing facultative anaerobe (designated as Clostridium sp. Tr2) from dung-feces in Vietnam.

\section{Materials and methods}

\subsection{Strain and medium}

The mesophilic, facultative strain $\operatorname{Tr} 2$ used in this study was identified as Clostridium sp. Tr2 based on 16S rRNA analysis (Nguyen et al., 2013). This strain was taken from the culture collection of IBT (Institute of Biotechnology), VAST (Vietnam Academy of Science and Technology).

The basic medium used in the present work was NMV medium adjusted basing on results of previous works (Nguyen et al., 2012; Dang et al., 2013).

\subsection{Cultivation}

Fermentation under the optimal condition: The optimal condition for strain $\operatorname{Tr} 2$ dark fermentation was defined in our previous reports (Nguyen et al., 2012; Dang et al., 2013). Then dark fermentation of strain Tr2 was performed in $600 \mathrm{ml}$ serum bottles that contained $500 \mathrm{ml}$ optimal NMV medium with $10 \%$ overnight culture that was in $\log$ phase of growth under $30^{\circ} \mathrm{C}$, initial $\mathrm{pH} 6.5$. These bottles were air-sealed with butyl rubber stopper and tied with aluminium seal cap. The optimal medium for hydrogen producing bacterium Clostridium sp. Tr2 is NMV medium basing on results Nguyen et al., 2012; Dang et al., 2013 in which some critical adjustments are glucose $10.18 \mathrm{~g}(\mathrm{~L})^{-1}$, yeast extract $2.5 \mathrm{~g}(\mathrm{~L})^{-1}$, no need meat extract, $\mathrm{FeSO}_{4} \cdot 7 \mathrm{H}_{2} \mathrm{O} 58 \mathrm{mg}(\mathrm{L})^{-1}$. During dark fermentation at $600 \mathrm{ml}$ bottle scale, the cell density and the volume of gas mixture were examined at each $4 \mathrm{~h}$ interval until hydrogen production was ceased. The quality of gas product was analysed at the end of experiment.

For controlled pH experiment: Both experiments (noncontrolled and controlled $\mathrm{pH}$ ) were carried out in $120 \mathrm{ml}$ serum bottles with $100 \mathrm{ml}$ medium with initial $\mathrm{pH} 6.5$. These bottles were air-sealed with butyl rubber stopper and tied with aluminium seal cap. Experiments were performed in optimal NMV media (mentioned above) for strain Tr. 2 with $10 \%(\mathrm{v} / \mathrm{v})$ inoculum of pre-culture that was in $\log$ phase of growth under facultative anaerobic condition at $30^{\circ} \mathrm{C}$, initial $\mathrm{pH}$ 6.5. $\mathrm{pH}$ media during fermentative process were estimated $4 \mathrm{~h}$ per time. When the strain grew, $\mathrm{pH}$ would be decreased. When $\mathrm{pH}$ reduced at pH 6.0, one bottle was keeping at constant value $\mathrm{pH} 6.0$ by feeding $\mathrm{NaOH}(5 \mathrm{M})$, the other was not controlled $\mathrm{pH}$ until hydrogen production was ceased. At each $4 \mathrm{~h}$ interval, the cell density and the total gas volume were also measured.

For batch 7 L automatic fermentor system scale (BioFlo 110): Strain $\operatorname{Tr} 2$ was pre-cultured twice, first in $120 \mathrm{ml}$ serum bottles with $100 \mathrm{ml}$ medium and then second in $600 \mathrm{ml}$ serum bottles with $500 \mathrm{ml}$ medium under facultative anaerobic fermentation at $30^{\circ} \mathrm{C}$. The hydrogen production capacity was checked during pre-cultivation. Ten percent $(\mathrm{v} / \mathrm{v})$ of second pre-culture was used as inoculum for dark fermentation in $7 \mathrm{~L}$ automatic fermentor containing 5.6 L medium under facultative condition. The temperature was maintained at $30^{\circ} \mathrm{C}$ by a heating jacket. $\mathrm{pH}$ was adjusted to 6.5 at the beginning of experiment. When $\mathrm{pH}$ was down to 6.0 , it was controlled at 6.0 through peristaltic pumps connected with alkali reservoirs $(5 \mathrm{M}$ $\mathrm{NaOH})$ until hydrogen production ceased. The evolved gas mixture was measured $2 \mathrm{~h}$ per time. For analysis, 10 $\mathrm{mL}$ of the fermentation broth was drawn at each $2 \mathrm{~h}$ interval. The mixed liquor samples were used to analyse the glucose consumption and to measure the cell density. The volume of gas product was continuously collected and recorded at each $2 \mathrm{~h}$ interval. The quality of gas product and by-products volatile fatty acids, ethanol and butanol were analysed at the end of experiment. The dark fermentation was carried out until hydrogen production was ceased. 


\subsection{Analyses}

Bacteria growth; glucose concentration; volume of gas mixture were perform as mentioned in Nguyen et al., 2014.

The quantity and composition of gas products (mainly, $\mathrm{H}_{2}$ and a little of $\mathrm{CO}_{2}$ and $\mathrm{H}_{2} \mathrm{~S}$ ) were determined in a gas chromatograph GC-TCD (Thermo Trace GC-Thermo Electro-USA) equipped with a thermal conductivity detector (TCD) and a column packed Molecularsieve 13X $5 \mathrm{~m}$. The operational temperatures of the oven and the detector were $50^{\circ} \mathrm{C}$ and $200^{\circ} \mathrm{C}$, respectively. Heli was used as the carrier gas at a flow rate of $25 \mathrm{mLmin}^{-1}$.

The concentrations of volatile fatty acids (acetic acid and butyric acid) as by-products were analyzed by high pressure liquid chromatography HPLC-PDA (Shimadzu, Japan) equipped with UV detector at $210 \mathrm{~nm}$ and column Supecogel $\mathrm{C} 610 \mathrm{H}$ coated with $1 \% \mathrm{H} 3 \mathrm{PO} 4$ at a flow rate of $0.5 \mathrm{mLmin}^{-1}$. The temperature of the injection port was $30^{\circ} \mathrm{C}$.

The by-products ethanol and butanol were also detected by GC-MS (Polaris Q Thermo Electro-USA) with a col- umn packed HP1-MS-(30m x $0.15 \mathrm{~mm}$ x $0.25 \mu \mathrm{m})$. Heli was used as the carrier gas at a flow rate of $1 \mathrm{mLmin}^{-1}$. The temperature of the injection and interface oven was $200^{\circ} \mathrm{C}$. The temperature for column oven: starting temperature $40^{\circ} \mathrm{C}$, temperature was raised up $6^{\circ} \mathrm{C}$ per min, then kept constantly at $230^{\circ} \mathrm{C}$ for $10 \mathrm{~min}$.

\section{Results and discussion}

\subsection{Biohydrogen production of strain Tr2 by dark fermentation under bottle scale}

The results of the dark fermentation in optimal NMV medium of strain Tr.2 was shown in Figure $1 \& 2$. These results emphasized that $\mathrm{H}_{2}$ production of strain $\mathrm{Tr} 2$ was also accompanied with growth and glucose consumption. $\mathrm{H}_{2}$ production began when strain $\operatorname{Tr} 2$ entered the early exponential growth phase and rate of $\mathrm{H}_{2}$ production reached a maximum in the late exponential growth phase. These finding are the similar with our previous report of strain Trau DAt (Nguyen et al., 2014).

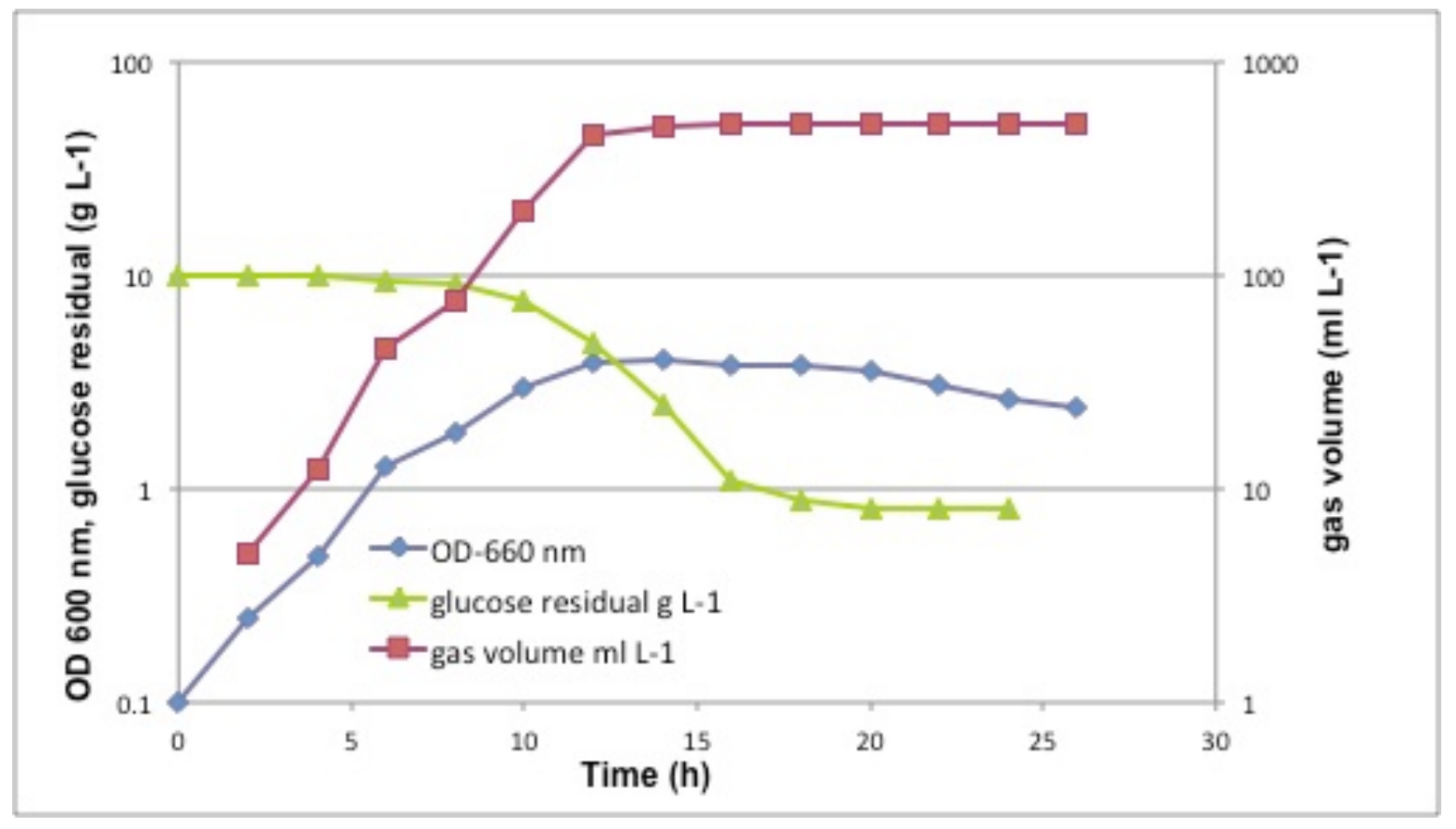

Figure 1. Capability of growth, hydrogen production, glucose consumption of strain Tr2 under optimal condition dark fermentation at bottle scale

Figure 1 also pointed out that strain $\operatorname{Tr} 2$ consumed about $9.3 \mathrm{~g}$ glucose $(\mathrm{L})^{-1}$ (initial glucose concentration was $\left.10.18 \mathrm{~g}(\mathrm{~L})^{-1}\right)$ to produce $1020 \mathrm{ml}$ gas mixture (L medi$\mathrm{um}^{-1}$ (Figure1). The gas analyses showed that the gas mixture contain hydrogen, $\mathrm{CO}_{2}$ and $\mathrm{H}_{2} \mathrm{~S}$ with $72.6 \%$, $1.2 \%$ and $26.1 \%$, respectively (Figure 2 ). Basing on these results, it was realized that real hydrogen volume was produced by strain Tr.2 under bottle scale on optimal NMV medium was $740 \mathrm{ml}$ (L medium) $)^{-1}$.
In comparison with our previous reported strain Trau DAt (Nguyen et al., 2014), the $\mathrm{H}_{2}$ obtained volume of strain Tr2 is higher than strain Trau DAt even though the gas quality is lower. However, the different wasn't so much distinguished. It implies that both our thermophilic, anaerobic bacterium Thermoanaerobacterium aciditolerans Trau DAt and mesophilic, facultative Clostridium sp. Tr2 are effective hydrogen producer using glucose as carbon source $(96.67 \%$ and $91.36 \%$ glucose consumption for each respective strain). 


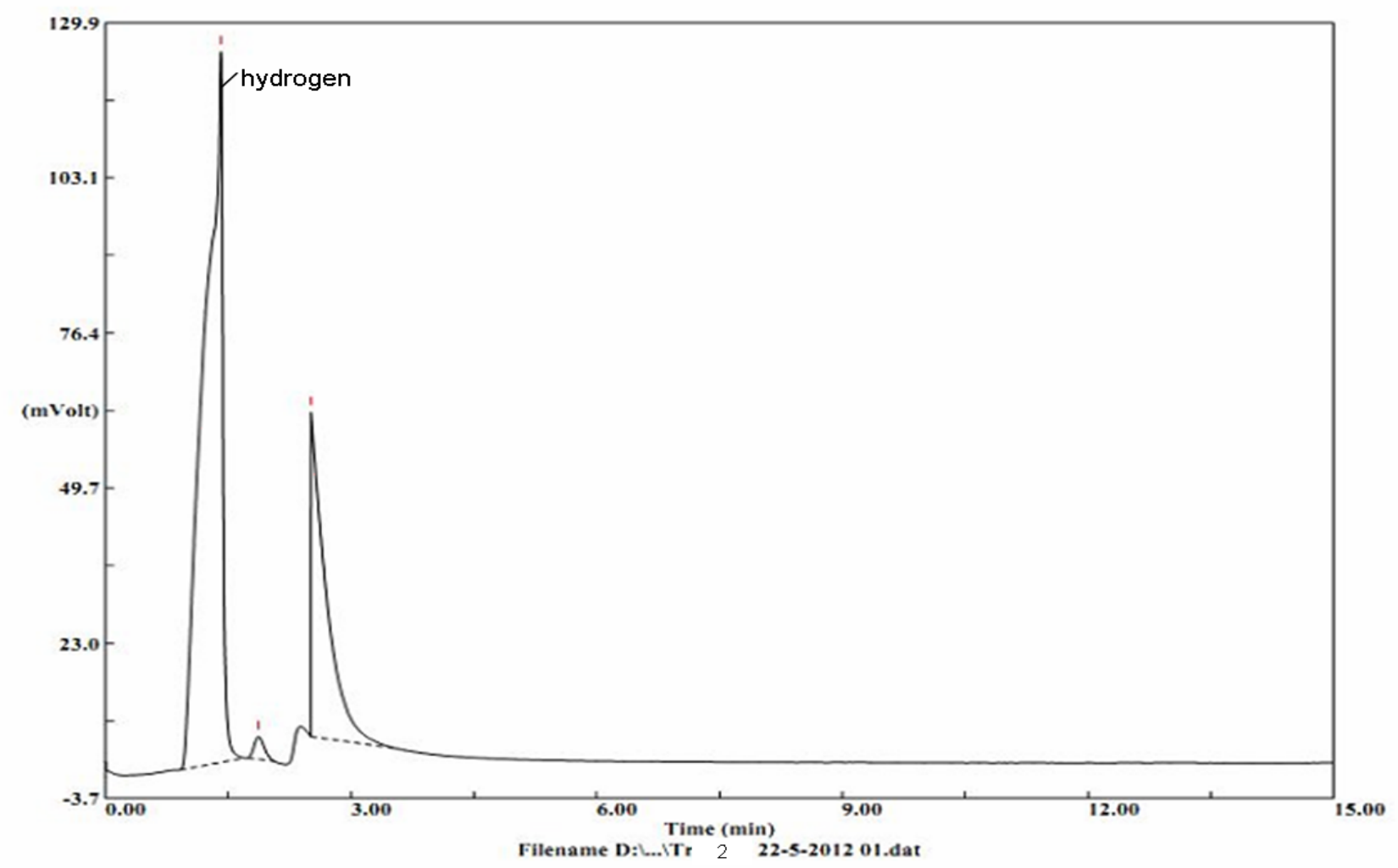

Figure 2. Chromatograph of gas product of strain Tr2 under optimal condition dark fermentation at bottle scale

\subsection{Hydrogen production of strain Tr2 un- der controlled $\mathrm{pH}$ condition}

Many papers including our previous paper indicated that dark fermentation by hydrogen producing bacteria depends on not only nutritional factors but also $\mathrm{pH}$ [DavilaVazquez al., 2008; Li et al., 2010; Khanna et al., 2011; Nguyen et al., 2012; 2014; Dang et al., 2013]. In our early study, it was found that $\mathrm{pH}$ of the medium was descended during the fermentation process of strain Tr2. It was also found that the maximum hydrogen production was observed when $\mathrm{pH}$ was 6.0. At $\mathrm{pH} 3-4$, the hydrogen production of strain $\operatorname{Tr} 2$ was ceased (data not shown). Thus, in this study, the experiment in which initial $\mathrm{pH} 6.5$ was set up and then operational $\mathrm{pH}$ was controlled at 6.0 was performed in order to find out whether controlled $\mathrm{pH}$ could increase the hydrogen production potential of strain $\operatorname{Tr} 2$.

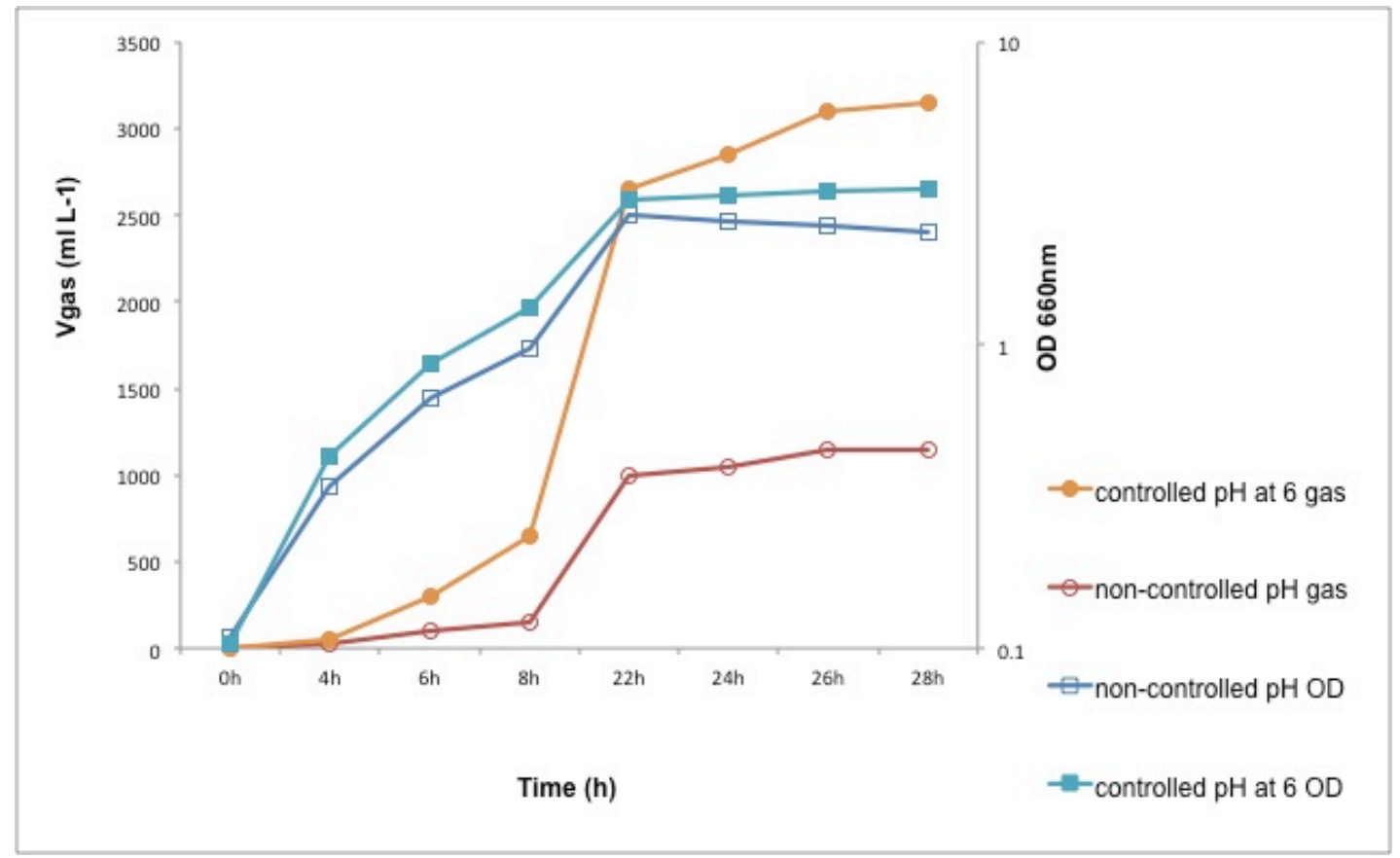

Figure 3. Effect of pH control on the growth and hydrogen production of strain Tr2 
The result shown in Figure3 indicated that hydrogen production capacity of strain $\operatorname{Tr} 2$ was highly affected by operational $\mathrm{pH}$. The gas production rate $\left(\mathrm{ml} \mathrm{h}^{-1} \mathrm{~L}\right.$ medi$\mathrm{um}^{-1}$ ) of strain $\operatorname{Tr} 2$ was 71.4 and 41 under controlled and non-controlled $\mathrm{pH}$ condition, respectively. The gas volume produced by strain $\mathrm{Tr} 2$ under controlled $\mathrm{pH}$ was much higher than that under non-controlled $\mathrm{pH}$. It implied that hydrogen fermentation condition was favorably maintained by $\mathrm{pH}$ control in the cultures. These findings are in agreement with results of Lee et al. (2008), Alalavah et al. (2009) that hydrogen yield is maximum if dark fermentation of hydrogen producing bacteria is started with initial $\mathrm{pH}$ at 6.5 and keep the constant at $\mathrm{pH}$ 6. Our results also were good evidences for the conclusion that constant $\mathrm{pH}$ improve hydrogen yields and rate of productivity
(Skonieczny and Yargeau, 2009; Li et al., 2010; Khanna et al., 2011; Nguyen et al., 2014).

\subsection{Dark fermentation for hydrogen produc- tion at fermenter scale}

Basing on above result and our previous reports [Nguyen et al., 2012; Dang et al., 2014], the dark fermentation of strain $\operatorname{Tr} 2$ was carried out at automatic fermenter system scale (Bio-Flo 110) using optimal NMV medium with some critical adjustments: $10.18 \mathrm{~g}(\mathrm{~L})^{-1}$ glucose, $2.5 \mathrm{~g}(\mathrm{~L})^{-}$ 1 , yeast extract, $58 \mathrm{mg}(\mathrm{L})^{-1} \mathrm{FeSO}_{4} \cdot 7 \mathrm{H}_{2} \mathrm{O}$, meat extract $0 \mathrm{~g}$ $(\mathrm{L})^{-1}, \mathrm{NaCl} 0 \mathrm{~g}(\mathrm{~L})^{-1}, 10 \%$ log-phase overnight second inoculums (v/v), initial $\mathrm{pH} 6.5$ and then $\mathrm{pH}$ was automatically controlled at 6.0 during fermentative process.

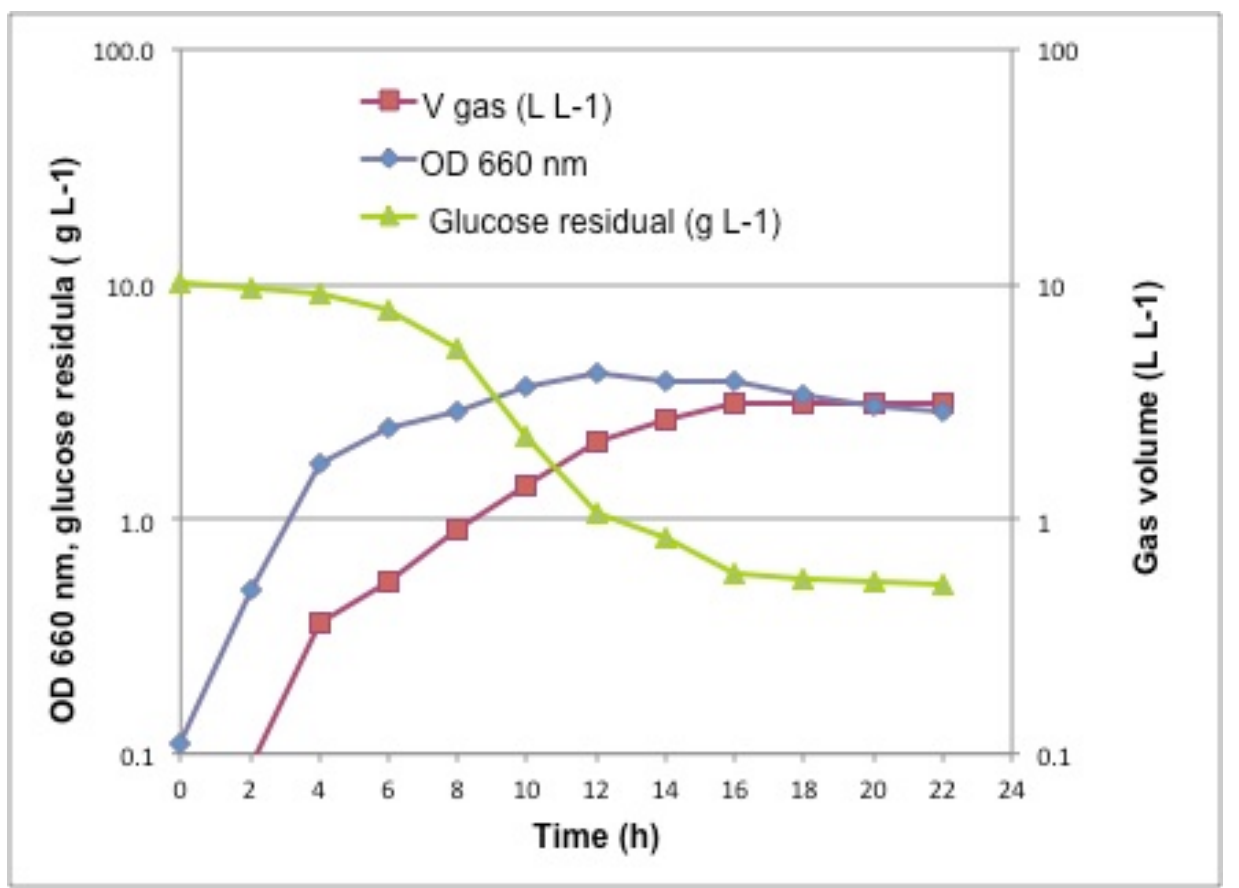

Figure 4. Capability of growth, hydrogen production, glucose consumption of strain Tr2 under optimal condition dark fermentation in automatic fermenter system

The results represented in Figure 4 show that strain $\operatorname{Tr} 2$ nearly had no lag phase and went intermediately to log phase. Then, it grew quickly and entered the stationary phase after cultivating 12 hours. Along with the growth, the gas product was generated after 2 hours cultivation, then was quickly enhanced since 6 hours fermentation. The total gas volume reached when experiment was finished was $3.07 \mathrm{~L}$ (L medium $)^{-1}$.

These obtained results emphasized that strain $\operatorname{Tr} 2$ grew faster under fermenter scale than under bottle one. It resulted from twice pre-cultivation and automatic controlled during main fermentation in Bioflo fermenter. Twice precultivation resulted in that cells were more homogeneous and almost were in the log phase so there is nearly no need time for the lag phase when cells were cultivated in main fermentation experiment. In addition, the amount of gas produced by strain $\operatorname{Tr} 2$ in this condition was more than bottle one. This result is obtained by maintaining the operating $\mathrm{pH}$ at $\mathrm{pH}$ 6. It can be said that twice pre- cultivation and maintaining $\mathrm{pH} 6$ help shorten the fermentation time and increase the amount of obtained gas, then lead to increase yield of fermentation.

Analysis of the by-products of fermentation showed that the by-products included acid acetic, acid butyric and butanol with little amount. Analyses of gas products showed that hydrogen mainly occupied $(95.82 \%)$ in comparison with $\mathrm{CO}_{2}(2.14 \%)$ and $\mathrm{H}_{2} \mathrm{~S}(2.03 \%)$ (Figure 5). These implied that strain $\operatorname{Tr} 2$ mainly fermented to produce hydrogen. Analyses of gas products also showed that the hydrogen quality obtained from these strains (95.82\%) under fermenter scale was significantly higher than under bottle scale $(72.6 \%)$. And the gas volume collected from fermenter $\left(3.07 \mathrm{~L}(\mathrm{~L} \text { medium })^{-1}\right)$ was also much higher than from bottle $\left(0.74 \mathrm{~L}(\mathrm{~L} \text { medium })^{-1}\right)$. These findings pointed out that the bigger scale, the more automatic control, the more controlled $\mathrm{pH}$ resulted the more hydrogen quality and yield in agreement with Nguyen et al., 2014. 


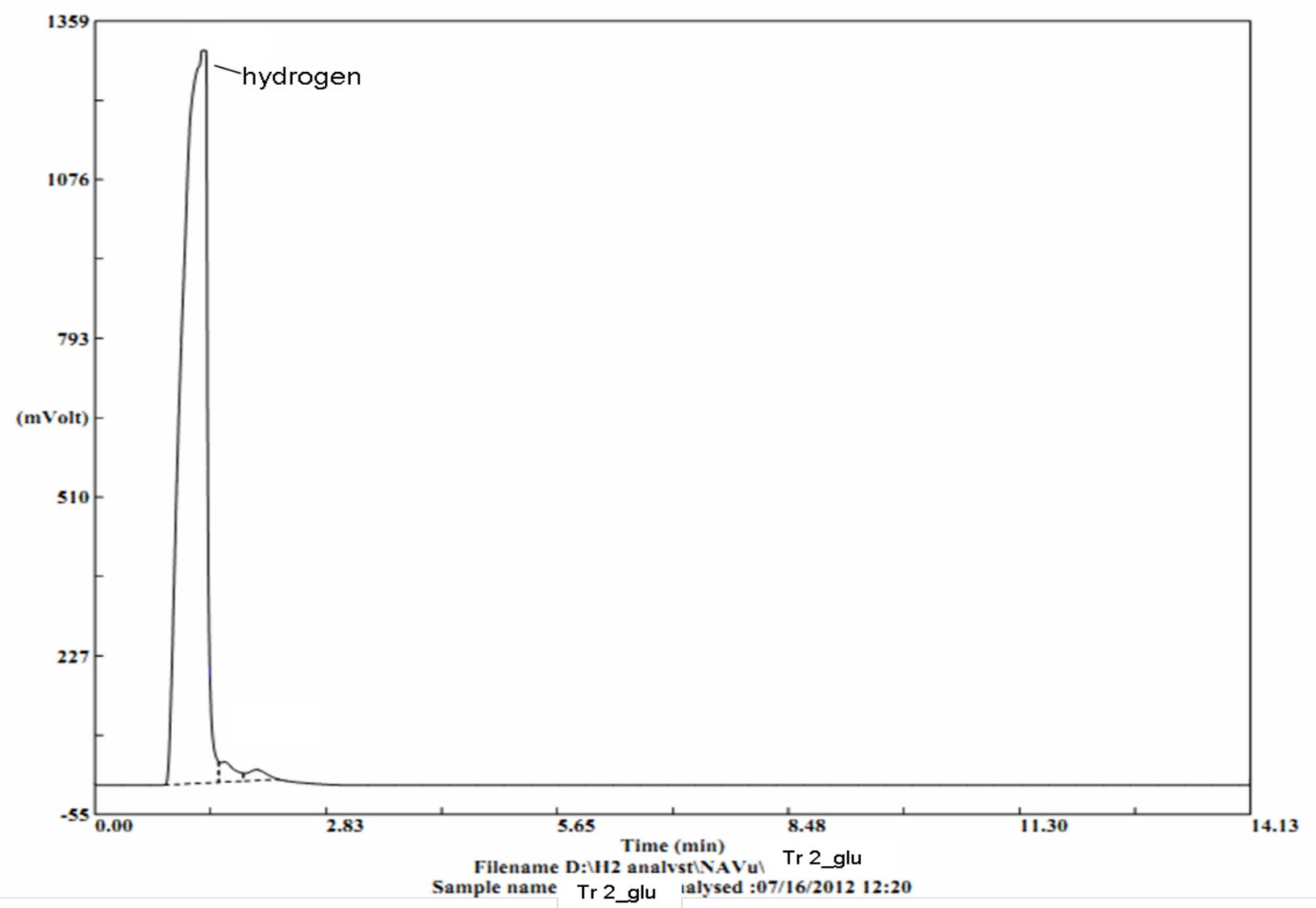

Figure 5. Chromatograth of gas product of strain Tr2 under optimal condition dark fermentation at fermentor scale

Results (Figure 4\&5) also showed that strain Tr2 consumed $9.6 \mathrm{~g}\left(\mathrm{~L}^{-1}\right.$ glucose $(94.3 \%)$ to produce $3.07 \mathrm{~L}$ gas $(\mathrm{L})^{-1}$ in which $\mathrm{H}_{2}$ occupied $95.82 \%$. Thus, hydrogen yield of strain Tr2 was 2.23 mol hydro (mol glucose $)^{-1}$. Compared to the theory that $1 \mathrm{~mol}$ of glucose can produce $2-4$ mol of hydrogen by dark fermentation, the yield of hydrogen fermentation of the studied strains is relatively high in comparison with previous reports [Alalayah et al., 2009; Oh et al., 2009; Khanna et al., 2011; Liu et al., Nguyen et al., 2014].

\section{Conclusion}

Obtained results of the present study showed that the hydrogen production capacity of Clostridium sp. Tr2 highly depended on the fermentation condition, especially $\mathrm{pH}$. Fermentation started with initial $\mathrm{pH}$ at 6.5 and kept the constant at $\mathrm{pH} 6$ enhanced the hydrogen production yield and rate of strain $\operatorname{Tr} 2$. In addition, twice increasing volume scale pre-cultivation, automatic control fermentor could also contribute to increase the quality and volume of obtained hydrogen product. At bottle scale, strain $\operatorname{Tr} 2$ produced $740 \mathrm{ml} \mathrm{H}_{2}$ (L medium) ${ }^{-1}$ occupied $72.6 \%$ of total gas. The maximum volume of total gas produced by the strain $\operatorname{Tr} 2$ was $3.07 \mathrm{~L}$ (L medium) $)^{-1}$ corresponding to $2.94 \mathrm{~L} \mathrm{H}_{2}$ ( $\mathrm{L}$ medium) ${ }^{-1}$, equivalent to $2.23 \mathrm{~mol} \mathrm{H}_{2}$ (mol glucose $)^{-1}$ under the optimal condition and maintainable pH 6.0 in automatic fermentor system BioFlo 110 .
Acknowledgement: The authors gratefully acknowledge the financial support of Vietnam Academy of Science and Technology (Grant No. VAST 05.02/1112). We also would like to express our thanks to Institute for Research and Development of natural products, Hanoi Technical University for their help in the gas and fermentation by-product analyses.

\section{References}

[1] Alalayah MW, Kalil SM, Kadhum HA, Jahim MJ, Alauj MN (2009) Effect of Environmental Parameters on hydrogen Production using Clostridium saccharoperbutylacetonicum N1-4 (ATCC 13564). American J. Environ. Sci., 5(1): 80-86.

[2] Chu CY, Tung L, Lin CY (2013) Effect of substrate concentration and $\mathrm{pH}$ on biohydrogen production kinetics from industry wastewater by mixed culture. Int. J. Hydrogen Energy, 38:15849-15855

[3] Dang TY, Vuong TN, Lai TH, Nguyen TTT (2013) Effect of environment parameters on hydrogen production of strain Tr2 isolated in Vietnam under microaerobic condition. J. Sci.\&Tech. 51 (5): 587-597.

[4] Das D, Veziroglu T, (2008) Advances in biological hydrogen production processes. Int. J. Hydrogen Energy 33: 6046-57.

[5] Davila-Vazquez G, Alatriste-Mondrago'n F, de Leo'n Rodri'guez A, Razo-Flores E (2008) Fer- 
mentative hydrogen production in batch experiments using lactose, cheese whey and glucose: influence of initial substrate concentration and $\mathrm{pH}$. Int. J. Hydrogen Energy, 33(19): 4989-4997.

[6] De Gioannis G, Muntoni A, Polettini A, Pomi R. A (2013) review of dark fermentative hydrogen production from biodegradable municipal waste fractions. Waste Manage 33:1345-61.

[7] Gupta SK, Kumari S, Reddy K, Bux E (2013) Trends in biohydrogen production: Major challenges and state of the art development. Environ. Technol., 34 (13-16): 1653-1670

[8] Khanna N, Kotay MS, Gilbert J, Das D (2011) Improvement of biohydrogen production by Enterobacter cloacae IIT-BT 08 under regulated $\mathrm{pH}$. Biotechnol., 152: 9-15.

[9] Kotay SM, Das D, (2008) Biohydrogen as a renewable energy resource-prospects and potentials. Int. J. Hydrogen Energy 33: 258-63.

[10] Kothari R, Singh DP, Tyagi VV, Tyagi SK, (2012) Fermentative hydrogen production-an alternative clean energy source. Renew Sustain Energy Rev. 16: 2337-46.

[11] Lee HS, Vermaas WFJ, Rittmann BE (2010) Biological hydrogen production prospects and challenges. Trends Biotechnol. 28: 262-271.

[12] Lee KS, Hsu YF, Lo YL, Lin PJ, Lind CY, Jo-Shu Chang JS (2008) Exploring optimal environmental factors for fermentative hydrogen production from starch using mixed anaerobic microflora. Int. J. Hydrogen Energy, 33: 1565-1572.

[13] Li Y, Zhu J, Wu X, Miller C, Wang L (2010) The effect of $\mathrm{pH}$ on continuous biohydrogen production from swine wastewater supplemented with glucose. Appl. Biochem. Biotechnol., 162: 1286-1296.

[14] Liu IC, Whang LM, Ren WJ, Lin PY (2011) The effect of $\mathrm{pH}$ on the production of biohydrogen by Clostridia: Thermodynamics and metabolic considerations. Int. J. Hydrogen Energy 36: 439-449

[15] Mudhoo A, Forster-Carneirob T, Sánchez A (2011) Biohydrogen production and bioprocess enhancement: A review. Critical review on Biotech. 31(3): 250-263
[16] Nguyen TTH, Dang TY, Nguyen TY, Vuong TN, Lai TH (2012) Using of response surface methodology for optimization of biohydrogen production by Clostridium sp. Tr2 isolated from Vietnam. J. Bio. 34(4): 479-484.

[17] Nguyen TTH, Nguyen TY, Vuong TN, Dang TY, Nguyen TT, Lai TH (2013) Selection and identification of some hydrogen producing bacteria isolated from cattle feces in Vietnam. J. Biotech., 35 (3SE): 79-87.

[18] Nguyen TY, Lai TH, Nguyen TTH (2014) Fermentative biolydrogen production by anaerobic, thermophilic bacterium Thermoanaerobacterium aciditolerans Trau DAt isolated from Vietnam. J. Bio. 36(4): 515-521.

[19] Ntaikou I, Antonopoulou G, Lyberatos G (2010) Biohydrogen production from biomass and wastes via dark fermentation: a review. Waste Biomass Valorizat 1: 21-39.

[20] Oh S, Zuo Y, Zhang H, Guilitinan JM, Logan EB, Regan MJ (2009) Hydrogen production by Clostridium acetobutylicum ATCC 824 and megaplasmiddeficient mutant M5 evaluated using alarge headspace volume technique. Int. J. Hydrogen Energy, 34: 9347-9353.

[21] Ren N, Guo W, Liu B, Cao G, Ding J, (2011) Biological hydrogen production by dark fermentation: challenges and prospects towards scaled-up production. Curr. Opin. Biotechnol., 22: 365-70.

[22] Shah TA, Afzal A, Ali S (2017) A review on biohydrogen as a propective renewable energy. Int. J. Biosci. 11(1): 106-130

[23] Show KY, Lee DJ, Tay JH, Lin CY, Chang JS (2012) Biohydrogen production: current perspectives and the way forward. Int. J. Hydrogen Energy, $37: 15616-31$.

[24] Skonieczny TM, Yargeau V (2009) Biohydrogen production from wastewater by Clostridium beijerinckii: Effect of $\mathrm{pH}$ and substrate concentration. Int. J. Hydrogen Energy, 34: 3288-3294.

[25] Wong YM, Wu TY, Juan JC (2014) A review of sustainable hydrogen production using seed sludge via dark fermentation. Renew Sustain Energy Rev., 34: 471-82. 